\title{
Reseña
}

\author{
Review
}

\section{Leticia Mayer Celis. Rutas de incertidumbre. Ideas alternativas sobre la génesis de la probabilidad, siglos XVI y XVII. México: Fondo de Cultura Económica, 2015, 298 pp.}

\author{
Karen Lorena Álvarez Sánchez \\ Universidad de Antioquia \\ karen.alvarezs@udea.edu.co
}

Fecha de recepción: 10 de agosto de 2018 Fecha de aprobación: 12 de diciembre de 2018

Rutas de incertidumbre. Ideas alternativas sobre la génesis de la probabilidad, siglos XVI y XVII, es un libro que versa sobre la historia de las ciencias, en este caso, acerca de la probabilidad. Esta ciencia, naturalmente compleja, y que, según el filósofo Ian Hacking, tuvo sus orígenes en el siglo XVII cuando comienza a desarrollarse con relación a los juegos de azar (de acuerdo a los textos de las Cartas Provinciales entre Pascal y Fermat), es lo que estudia, interpreta y discute la autora mexicana Leticia Mayer Celis en este libro. Explicando que su surgimiento "no se hubiera podido dar sin la existencia de una construcción sociocultural anterior"1, la autora sugiere el vínculo con el pasado y cierto contexto cultural que influyó al momento en que las primeras ideas que sustentan esta forma de conocimiento comenzaron a configurarse.

Según la autora, el riesgo, la duda y la incertidumbre son componentes esenciales que fundamentan la idea humana (y humanista) de buscar respuestas que conduzcan hacia un tipo de certeza probable; buscando razones de acuerdo a casos particulares, y haciendo inferencias a partir de esa incertidumbre generada. Lo anterior correspondería a la probabilidad epistémica que, según se plantea y argumenta a lo largo del libro, no hubiera sido posible sin la existencia activa y previa del probabilismo: "la corriente moral que acepta que se puede actuar dentro de escenarios de incertidumbre de acuerdo con las opiniones de hombres probos, de forma razonable en conformidad con las circunstancias concretas y los espacios geográficos y culturales concretos con

1 Mayer, Rutas de incertidumbre. Ideas alternativas sobre la génesis de la probabilidad, siglos XVI y XVII, 21. 
los que se interactúa" ${ }^{\prime 2}$. Así, su aparición parte, principalmente, de lo problemático que resultó para Occidente el encuentro con el otro (América y Asia). Aquí se exhibe la profundización sobre la compleja discusión teológico-moral de los siglos XVI y XVII entre este movimiento probabilista con el probabiliorismo. En esta discusión, nada sencilla en términos teológicos, cuyo riesgo era la pérdida de la salvación y la vida eterna del alma, se cuestionan los principios de autoridad de occidente, la Ley Natural (poniendo en duda también la existencia de leyes universales) y el Derecho Natural, todo a partir de la duda, miedo, impacto, rechazo e incertidumbre, entre otros, que significaron el encuentro con el otro, con culturas disímiles; algo a lo que la autora se refiere como los dos grandes descubrimientos: el de América y el de las rutas marítimas por el océano Pacífico. Partiendo de estos dos grandes acontecimientos, la autora alude a lo que implicó ese primer encuentro y cómo este se reflejó e impactó en Europa, sin dejar de lado el protagonismo que en estas discusiones tuvieron los miembros de la Compañía de Jesús por medio de sus misiones evangelizadoras hacia estos lejanos lugares.

Mayer Celis nos muestra cómo a partir de influencias probabilistas tuvieron lugar ciertos procesos sincréticos con los nativos de Mesoamérica, encabezados por los misioneros jesuitas que arribaron a la Nueva España. Estas negociaciones simbólicas, vistas también como tolerancia, acomodación, adaptación o aceptación de viejas costumbres idolátricas, permiten observar esa flexibilidad respecto al seguimiento de los principios de autoridad. Aquello implicó el correr ese "horrible riesgo moral" constituido por la pérdida de la vida eterna. Por otro lado, sería en el continente asiático donde el probabilismo se experimentó en su máximo esplendor. Fueron los procesos de aculturación, las actitudes permisivas en el modo de evangelizar, evidentemente probabilistas y casuistas frente a las formas de actuar y de pensar del otro, producto de la fascinación que generó en los misioneros jesuitas la grandeza del Imperio del Centro, las acciones que más alarmaron a Occidente.

Al abordar las discusiones teológicas desarrolladas en Europa, pero también en América, escenarios donde participaron personajes rigoristas y jansenistas en un debate moral contra, principalmente, los misioneros jesuitas en Oriente, probabilistas y casuistas, la autora tuvo acceso a la carta Inocencia Tercera, que el obispo de Puebla de los Ángeles, Juan de Palafox y Mendoza, le envió al Papa Inocencio X, donde "denuncia" las labores misionales de la Compañía de Jesús en Oriente, explicando el modo cómo se están llevando a cabo y lo contrariado que estuvo por la "falsa cristianización" debido a la "teología moral relajada de los casuistas probabilistas". Esta carta que se difundió profusamente en Europa, causando varios escándalos debido al inconveniente que significaba poner en riesgo la vida eterna de los nuevos

2 Mayer, Rutas de incertidumbre. Ideas alternativas sobre la génesis de la probabilidad, siglos XVI y XVII, 15.

Artificios. Revista colombiana de estudiantes de historia. No. 13. Mayo de 2019. ISSN. 2422-118X 
cristianos, no podía pasar desapercibida en este contexto. La autora conjetura entonces que la Inocencia Tercera, o los debates a partir de ella, influyeron en la filosofía moral de Blaise Pascal, uno de los padres de la probabilidad y cultor de la doctrina rigorista, quien en sus cartas provinciales demostró su postura contra el probabilismo en virtud del riesgo moral que implicaba. Por ello se negó a dar el nombre de probabilidad a la ciencia en cuestión, influenciado por ese ambiente moral de debate, que más tarde terminaría por imponerse.

De esta manera, la autora defiende la influencia del probabilismo en el surgimiento de las ideas de la probabilidad: primero la epistémica y después la aleatoria, aquella que se usa en las matemáticas actuales. En un inicio, el libro puede parecer algo complejo por la variabilidad de temas y la complejidad de los conceptos imprescindibles para sus interpretaciones y argumentos, aunque más adelante se van desenvolviendo con soltura, lo que resulta vital para la comprensión general de la obra, asunto que la autora tuvo especial cuidado en aclarar. De forma muy ordenada, Mayer Celis aborda paso a paso cada uno de los temas, concluyendo y preparando al lector previamente a nuevas exposiciones, recapitulando sobre los problemas al final de cada capítulo, algo que permite al lector mantener el interés sin perder de vista el argumento principal del libro.

Para su hipótesis, sustentada en una notable cantidad de bibliografía y en fuentes primarias y secundarias, Leticia Mayer Celis recurre a documentación empleada como punto de partida del análisis y para debatir lo que ella denominó como la "génesis de la probabilidad". El surgimiento de la probabilidad. Un estudio filosófico de las ideas tempranas acerca de la probabilidad, la inducción y la inferencia, autoría de Ian Hacking, autor cuestionado con mucho respeto, es uno de los recursos documentales más predominantes; también destacan las cartas ya mencionadas: La Inocencia Tercera y Las cartas Provinciales que, según se entiende, son las que esencialmente orientaron la defensa y argumentos comportados en su hipótesis: "que el probabilismo le fue creando sentido a la duda moral que se desarrolló, particularmente, cuando Europa tuvo que enfrentar la existencia de hombres que vivían en culturas totalmente ajenas a las suyas"3. También seleccionó una serie de "láminas" -así llamadas en el texto- que ubicó en la parte central del libro, complementos que sustentan e ilustran muy bien algunos de los contenidos e ideas, yendo más allá de las descripciones, y agregando algunos anexos de mapas y redes para apreciar más claramente algunos puntos que dan mayor precisión a la obra en general.

La relevancia de esta obra la encontramos evidentemente para el campo de la historia de las ciencias, su aporte a esta rama de las matemáticas constituye un nuevo punto de vista. No obstante, y como lo señala la autora, con esta investigación también

3 Mayer, Rutas de incertidumbre. Ideas alternativas sobre la génesis de la probabilidad, siglos XVI y XVII, 249.

Artificios. Revista colombiana de estudiantes de historia. No. 13. Mayo de 2019. ISSN. 2422-118X 
es posible afirmar que los cimientos de la globalización estuvieron determinados por los contactos interculturales y civilizatorios consumados entre los siglos XVI y XVII; contactos con una otredad lejana y diferente, con la cual hubo intercambio de productos, conocimientos, objetos y, además coexistencia en los mismos espacios. Estos detalles, a su vez, representan una contribución, tanto en términos teóricos, así como empíricos, para la elaboración de una historia global.

También es preciso mencionar que el énfasis en las misiones de Asia, particularmente las desarrolladas en China, es un elemento utilizado por la autora para explicar los tempranos procesos de globalización. Este fenómeno es analizado de manera ecléctica acudiendo a análisis sustentados por aportes teológicos, jurídicos, náuticos y filosóficos para lograr una densa pero sugerente interpretación de los hechos comprometidos en los origenes de la probabilidad. Al acercarse a disciplinas tan diversas de forma convincente, Mayer Celis afirmó que temió por que su eclecticismo conllevara a resultados imprecisos. Sin embargo, cabe destacar que este libro demuestra todo lo contrario: es un estudio original, novedoso, crítico y metodológicamente versátil, que no se aparta de una narrativa agradable e inspiradora para comprender los primeros siglos del expansionismo europeo en Asia y América. 